\title{
PERBANDINGAN KADAR LEPTIN DAN TEKANAN DARAH PADA OBESITAS
}

\author{
Yulina Dwi Hastuty \\ Dosen Jurusan Kebidanan Medan \\ Email: yulinadwihastuty@gmail.com
}

\begin{abstract}
Abstrak
Latar belakang: Obesitas merupakan suatu kondisi dimana terdapat penimbunan lemak tubuh yang berlebihan, dan menjadi factor resiko untuk morbiditas dan mortalitas kardiovaskuler. Prevalensinya yang meningkat telah menimbulkan masalah kesehatan yang cukup serius. Studi prospektif mendapati bahwa obesitas viseral berkaitan erat dengan hipertensi, dislipidemia dan penyakit kardiovaskuler, meskipun mekanisme yang menghubungkannya belum dipahami sepenuhnya. Keterlibatan leptin diperkirakan berperan terhadap obesitas dan hipertensi mengingat leptin merupakan hormone yang disekresi sel lemak selain berfungsi sebagai pengatur asupan makan dan keseimbangan energy juga berperan pada tekanan darah melalui aktivitas syaraf simpatis. Tujuan dari penelitian ini untuk melihat perbandingan kadar leptin dan tekanan darah pada obesitas visceral dan non visceral.Metode: penelitian ini menggunakan disain cross sectional di wilayah kota Medan. Sampel dikelompokkan menjadi obesitas visceral dan non visceral dengan jumlah sampel tiap kelompok 20 orang yang diperoleh secara accidental sampling. Analisis hasil menggunakan program SPSS dengan tingkat kemaknaan $\mathrm{p}<0.05$. Hasil : kadar leptin antara obesitas visceral dan non visceral tidak berbeda nyata ( $\mathrm{p}>0.05)$, kadar leptin lebih tinggi pada perempuan dibanding laki-laki $(\mathrm{p}<0.05)$, tekanan darah systole lebih tinggi pada obesitas viseral dibanding non viseral $(p<0.05)$ sedangkantekanan darah diastole tidak berbeda nyata antara obesitas viseral dan non viseral ( $\mathrm{p}>0.05)$ Pada obesitas viseral dan non visceral didapati semakin tinggi kadar leptin maka tekanan darah semakin rendah.Saran : dalam penatalaksanaan masalah kesehatan yang terkait dengan obesitas dan hipertensi hendaknya mempertimbangkan peran leptin dalam peningkatan maupun penurunan tekanan darah.
\end{abstract}

Kata kunci : leptin, tekanan darah, obesitas, viseral, non visceral

\section{PENDAHULUAN}

Obesitas merupakan masalah global dinegara maju maupun negara berkembang. Prevalensi obesitas meningkat pada beberapa tahun terakhir dan telah menimbulkan masalah kesehatan yang serius.Secara global setidaknya 2,8 juta meninggal setiap tahun terkait dengan peningkatan berat badan dan obesitas dimana 300.000 terjadi di Amerika Serikat dan 350.000 di Asia Tenggara (Rahmouni et al, 2005:WHO/SEARO, 2011). Berdasarkan data dari Noncommunicable Disease in South-East Asia Region tahun 2008 prevalensi individu dengan IMT $\geq 25 \mathrm{~kg} / \mathrm{m}^{2}$ mengalami peningkatan dari $2.7 \%$ menjadi $8.9 \%$ di Bangladesh, $1.6 \%$ menjadi $10 \%$ di Nepal dan $11 \%$ menjadi $15 \%$ di India sedangkan di Indonesia persentasinya mencapai $16 \%$ pada laki-laki dan 25\% pada wanita (WHO/SEARO, 2011). Data yang diperoleh dari Riset Kesehatan Daerah (Riskesda) Sumatera Utara tahun 2010 menyebutkan persentase overweight pada laki-laki $10.9 \%$ dan $12.8 \%$ pada wanita, sedangkan persentase obesitas $9.4 \%$ pada lakilaki dan $17.4 \%$ pada wanita (Riskesda, 2010)
Meningkatnya jumlah individu dengan obesitas berdampak buruk bagi kesehatan, mengingat obesitas merupakan penyakit kronik yang bersifat poligenik atau monogenik yang dapat mengakibatkan beberapa keadaan disfungsi atau patologis (Klein \& Romijn, 2008). Beberapa hal yang dapat mempengaruhi obesitas diantaranya faktor genetik, asupan makanan, mekanisme neuroendokrin, sosial budaya dan gaya hidup (Librantoro, 2007). Di Indonesia, perubahan gaya hidup yang menjurus ke westernisasi menyebabkanberubahnya pola makan yang merujuk pada diet tinggi kalori, lemak dan kolesterol yang menimbulkan dampak terhadap peningkatan resiko obesitas (DirKes, 2009).

Peningkatan prevalensi obesitas dapat mengakibatkan peningkatan insiden hipertensi (Shintani, 2002). Analisis data dari beberapa daerah mendapatkan estimasi bahwa orang dewasa yang menderita hipertensi pada tahun 2000 adalah 972 juta, 333 juta berada di negara maju dan 639 juta pada negara berkembang. Proporsi ini akan meningkat mencapai $60 \%$ yaitu 1.56 milyar pada tahun 2025 (Kearney et al, 2005). Di Indonesia prevalensi hipertensi mengalami peningkatan, dari 8\% pada tahun 
1995 menjadi 32\% tahun 2008 (WHO/SEARO, 2011). Tahun 2007 prevalensi hipertensi mencapai 32,2\% dimana diprediksi masih terdapat $76 \%$ kasus hipertensi yang terjadi dimasyarakat belum terdiagnosa (Ekowati\& Sulistyowati, 2009).

Beberapa studi telah menemukan hubungan kuat antara obesitas dengan hipertensi (Francischetti, 2007). Studi Farmingham menyatakan bahwa 78\% hipertensi pada laki-laki dan 65\% hipertensi pada wanita berhubungan dengan obesitas. Resiko kejadian hipertensi meningkat sampai 26\% pada laki-laki yang obes dan $28 \%$ pada wanita yang obes dibanding dengan berat badan normal (Wilson et al, 2002). Fakta lain menunjukkan bahwa setiap peningkatan $10 \mathrm{~kg}$ berat badan berhubungan dengan peningkatan tekanan darah (TD) sistolik $3 \mathrm{mmHg}$ dan diastolik 2-3 mmHg. Menurut Inou dkk resiko hipertensi akan meningkat dua kali pada subjek obes yang mempunyai IME 25 $\mathrm{kg} / \mathrm{m}^{2}$ (Librantoro, 2007).

Obesitas diartikan sebagai kondisi terdapat penimbunan lemak tubuh yang berlebihan, secara normal lemak yang berlebih akan disimpan dilapisan subkutan, namun karena mengalami gangguan atau kerusakan maka lemak terakumulasi dilapisan viseral (Ibrahim, 2009). Obesitas merupakan faktor presdiposisi terjadinya hipertensi, dislipidemia, DM, penyakit kardiovaskuler, gagal ginjal dan respon inflamasi (Bravo, 2006).

Obesitas dibedakan menjadi obesitas abdominal atau viseral dan obesitas periper atau lower obesity atau non viseral (Wajchenberg, 2000; Klein \& Romijn, 2008). Lemak viseral memiliki reseptor glukokortikoid dan androgen lebih banyak, metabolism yang lebih aktif, lebih sensitive terhadap lipolisis dan lebih resisten insulin. Viseral Adipose Tissue (VAT) memiliki kapasitas lebih besar menghasilkan Free Fatty Acid (FFA), meningkatkan glukosa dan lebih sensitive terhadap stimulasi adrenergic (Ibrahim, 2009). Studi prospektif dengan menggunakan pengukuran antropometri mendapati bahwa obesitas viseral memiliki kaitan erat dengan hipertensi, diabetes dan penyakit kardiovaskuler (Tchernof, 2007).

Meskipun menjadi faktor resiko penting untuk morbiditas dan mortalitas kardiovaskuler, namun mekanisme yang menghubungkan obesitas dan gangguan kardiovaskuler khususnya hipertensi masih belum dipahami sepenuhnya(Aneja et al, 2004). Saat ini diketahui bahwa beberapa mekanisme telah terlibat, termasuk aktivitas yang berlebihan dari sistem syaraf simpatis(Aneja et al, 2004:Hall, 2003:Alvarez et al, 2002). Beberapa peneliti menemukan indikasi bahwaleptin berperan dalam hipertensiyang berhubungan dengan obesitas (Friedman, 1998 : Shintani, 2002: Correia, 2008: Haynes, 2005).

Leptin adalah hormon sel adiposa yang ditemukan tahun 1994 pada tikus yang obesitas (gen ob/ob) (Friedman, 1998). Penemuan hormon leptin membawa perspektif baru terhadap mekanisme obesitas dan penyakit terkait (Aizawa et al, 2000). Penelitian awal menunjukkan leptin berperan dalam mengatur nafsu makan dan meningkatkan pengeluaran energi (Friedman, 1998, Considine, 1996). Studi tambahan menunjukkan bahwa leptin juga menyebabkan eksitasi syaraf simpatis pada ginjal yang pada akhirnya akan meningkatkan tekanan arteri (Hall, 2003). Penelitian pada hewan menunjukkan bahwa tingkat leptin yang tinggi (hiperleptinemia) dapat mengaktifkan sistem syaraf simpatis dan menyebabkan peningkatan tekanan darah (Kamal et al, 2005). Hiperleptinemia dapat disebabkan obesitas melalui efek perifer dan hiperleptinemia juga dapat menyebabkan obesitas melalui efek sentral ( Martin et al, 2008).

Studi klinik yang dilakukan Khokhar et al 2010, menemukan kadar leptin lebih tinggi pada wanita yang hipertensi dibanding wanita normal dan korelasi positif antara tekanan darah dan leptin secara signifikan ditemukan pada wanita hipertensi baik obes maupun normal yang pre dan post menopause. Beberapa peneliti lainnya mendapat hasil bahwa kadar leptin berkorelasi positif baik pada wanita dan pria yang hipertensi (Henriksen et al, 2000: Shankar, 2010).

Hasil yang berbeda didapatkan dari hasil penelitian Almeida yang menyatakan bahwa kadar leptin memiliki hubungan yang signifikan dengan variabel antropometri tetapi tidak dengan tekanan darah pada wanita keturunan Jepang-Brazil (Almeida, 2006). Beberapa penelitian yang ada belum mengkaji bagaimana kaitan antara leptin dan tekanan darah pada berbagai tipe obesitas, karena itu penelitian ini bertujuan untuk melihat bagaimana perbandingan kadar leptin dan tekanan darah pada obesitas visceral dan non viseral.

\section{METODE}

Penelitian ini bersifat deskriptif analitik dengan disain cross sectional, Populasi target adalah semua orang yang masuk kategori obesitas baik obesitas viseral maupun non visceral yang berdomisili di kota Medan. Sampel penelitian adalah orang-orang yang memenuhi kriteria inklusi (IMT $\geq 25 \mathrm{~kg} / \mathrm{m}^{2}$, usia $\geq 20$ dan $<60$ tahun dan bersedia menjadi sampel).

Kriteria ekslusi pada penelitian ini adalah menderita penyakit kanker, hepatitis, ginjal, jantung dan diabetes, menggunakan obat jangka panjang (misalnya steroid, tiazolidinedione dll) dan menggunakan terapi hormone (estrogen,testosterone,insulin,dll). Sampel diperoleh dengan cara accidental sampling dan besar sampel minimal dihitung dengan menggunakan rumus perhitungan sampel untuk uji analitik numerik (Sastroasmoro, 2011).

Rumus : $\mathrm{n}_{1}=\mathrm{n}_{2}=2\left(\frac{(z \alpha+z \beta) \sigma}{x a-x o}\right)^{2}$

$\alpha=$ tingkat kemaknaan (ditetapkan peneliti)

$\alpha=0.05 \rightarrow z_{\alpha}=1.96$

$\beta=$ power of test (ditetapkan peneliti) $80 \% z_{\beta}=0.842$

$\sigma=$ simpangan baku $=7.9$ (penelitian sebelumnya)

$\mathrm{X}_{\mathrm{a}}-\mathrm{xO}=$ selisih rerata yang dianggap bermakna $\longrightarrow 4,5$

(Librantoro, 2007)

$\mathrm{n}_{1}=\mathrm{n}_{2}=2\left(\frac{(1.96+0.842) 7.9}{4.5}\right)^{2}=19.6 \rightarrow 20$ 
Jumlah sampel untuk kelompok obesitas visceral 20 orang dan non visceral 20 orang, sehingga total sampel berjumlah 40 orang.

Data diperoleh berdasarkan pengukuran berat badan (BB), tinggi badan(TB), lingkar pinggang (LP), lingkar panggul (LPa), tekanan darah (TD) dan kadar leptin. Data yang diperoleh diolah secara statistik dengan menggunakan SPSS. Untuk membandingkan kadar leptin antara kelompok yang diteliti digunakan uji $\mathrm{t}$ independent jika data kedua kelompok berdistribusi normal atau dengan uji mann Whitney bila distribusi data tidak normal. Untuk menguji perbedaan variabel kategorikal antara dua kelompok digunakan Chi-square. Perbedaan yang signifikan ditetapkan dengan nilai $\mathrm{p}<0.05$.

\section{HASIL}

Jumlah keseluruhan sampel sebanyak 40 orang yang masuk kategori obesitas berdasarkan pengukuran indeks massa tubuh (IMT). Keseluruhan sampel yang diikutkan dalam penelitian dibedakan menjadi obesitas viseral dan obesitas non viseral berdasarkan pengukuran lingkar pinggang (LP) dan rasio antara lingkar pinggang dan lingkar panggul (LPa). Data sampel penelitian dilakukan analisis seperti tertulis dibawah ini.

\section{Perbandingan leptin pada obesitas viseral dan non} viseral

Pada Gambar 1 dapat dilihat perbedaan kadar leptin antara kelompokobesitas non-viseral dengan kelompok obesitas viseral. Nilai rerata \pm simpangan baku kadar leptin pada kelompok obesitas non viseral adalah $28.712 \pm 9.37 \mathrm{pg} / \mathrm{ml}$ sedangkan pada kelompok obesitas viseral adalah $26.344 \pm 24.1 \mathrm{pg} / \mathrm{ml}$.

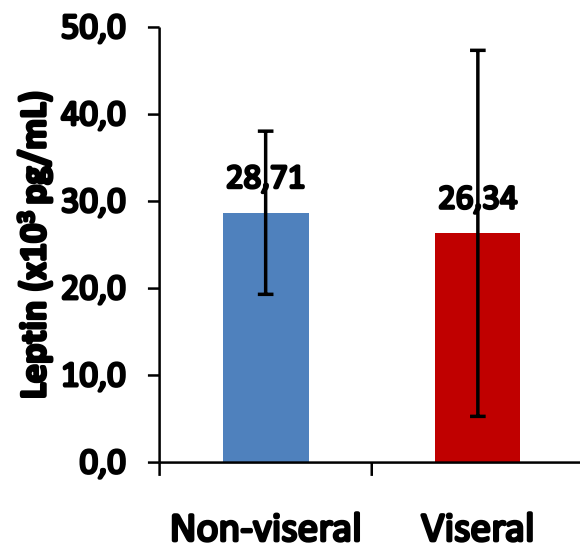

Gambar 1. Perbandingan kadar leptin pada obesitas viseral dan non viseral $(\mathrm{p}>0.05)$

\section{Perbandingan Tekanan Darah dengan Obesitas}

Perbandingan tekanan darah sistolik dan diastolic pada obesitas viseral dan non viseraldapat dilihat pada gambar 2 berikut ini.

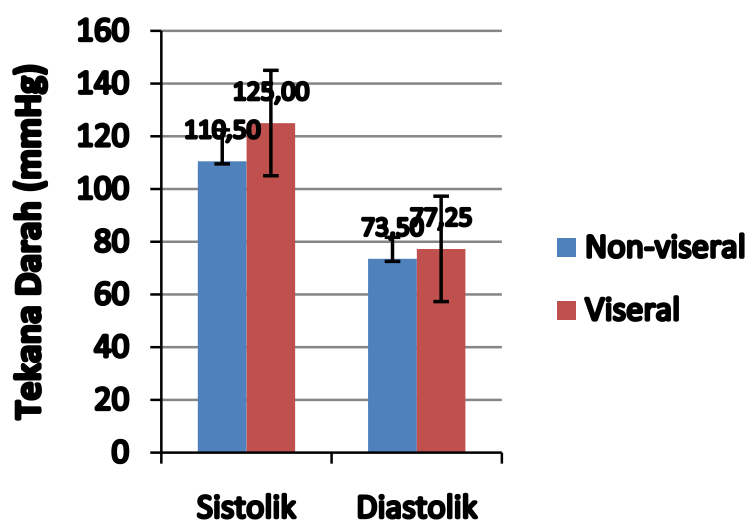

Gambar 2. Perbandingan tekanan darah systole pada obesitas viseral dan non viseral $(\mathrm{p}<0.05)$, perbandingan tekanan darah diastole pada obesitas viseral dan non viseral $(\mathrm{p}>0.05)$

Rerata tekanan darah sistolik pada obesitas viseral berbeda dibanding dengan rerata tekanan darah sistolik pada kelompok obesitas non viseral. Rerata tekanan darah sistolik pada kelompok obesitas viseral lebih tinggi secara signifikan dibanding rerata tekanan darah sistolik pada kelompok obesitas non viseral. Sedangkan rerata tekanan darah diastolic yang didapat dari penelitian ini tidak berbeda secara signifikan antara kelompok obesitas viseral dan kelompok obesitas non viseral.

Rerata tekanan darah sistolik pada kelompok obesitas viseral adalah 125.00 \pm 20.90 dan pada kelompok obesitas non viseral adalah $110.50 \pm 11.91$ sedangkan rerata tekanan darah diastolik pada kelompok obesitas viseral adalah 77.25 \pm 9.39 dan pada kelompok obesitas non viseral adalah 73.50 \pm 8.13 .

\section{Perbandingan Leptin dan Tekanan Darah}

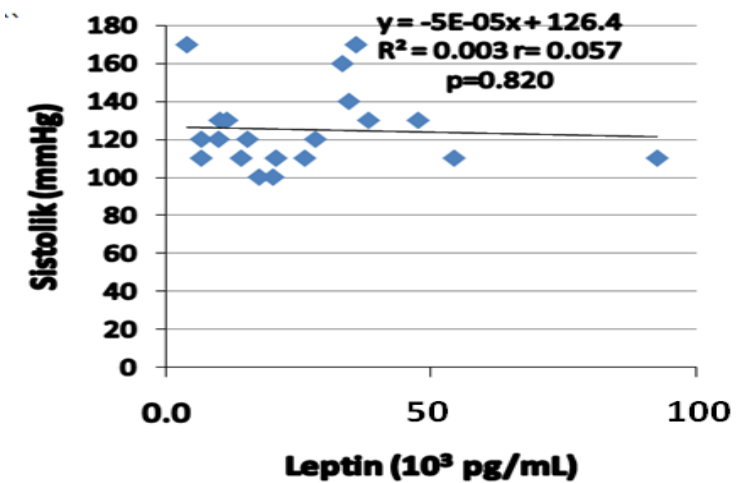

Perbandingan kadar leptin dan tekanan darah pada obesitas viseral dan non viseral dapat disimpulkan berdasarkan hubungan yang terlihat pada gambar 3 dibawah ini: 


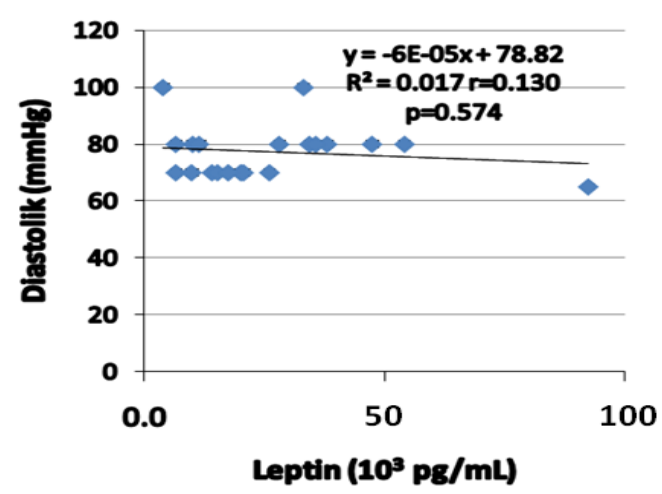

Gambar 3. Hubungan kadar leptin dan tekanan darah (sistolik dan diastolic) pada obesitas visceral.
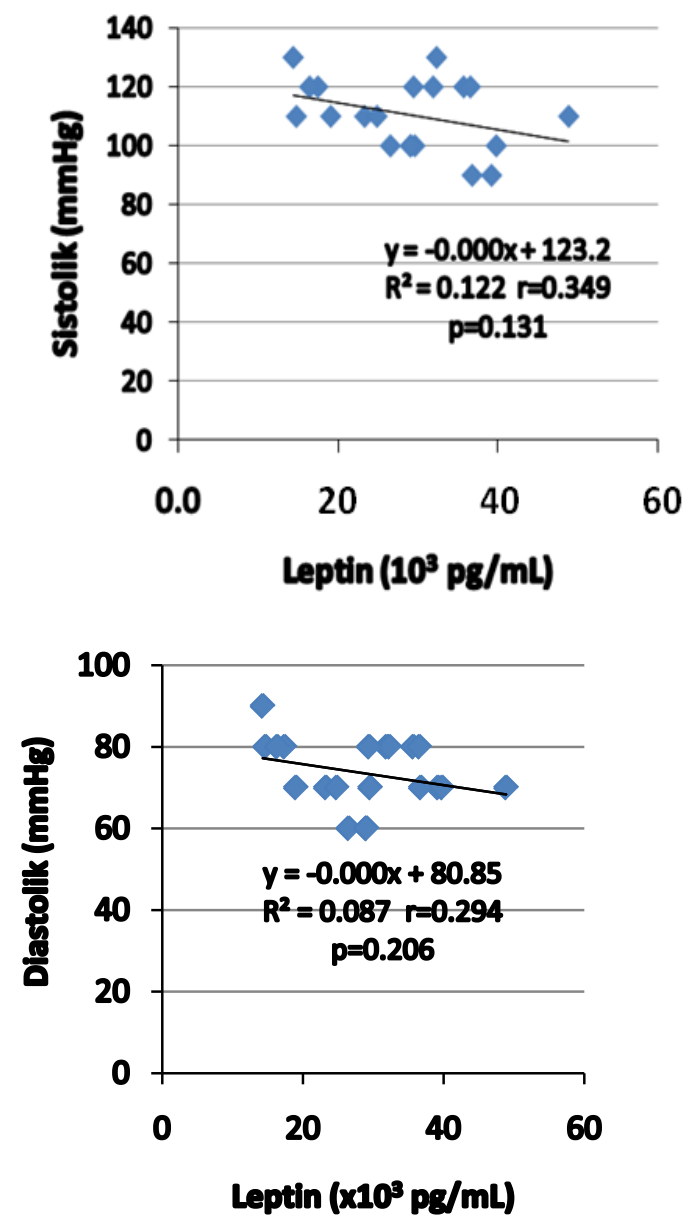

Gambar 4. Hubungan kadar leptin dan tekanan darah (sistolik dan diastolic) pada obesitas non visceral.

\section{PEMBAHASAN}

\section{Perbandingan Leptin pada obesitas viseral dan non} viseral.

Kadar Leptin mempunyai perbedaan yang tidak nyata $(\mathrm{p}>0,05)$ antara kelompok subjek nonvisceral dan visceral. Nilai rerata \pm simpangan baku kadar leptin pada kelompok obesitas viseral dan non viseral adalah $26.344 \pm 21.02 \mathrm{pg} / \mathrm{ml}$ dan28.712 \pm 9.37 pg/ml. Penelitian sebelumnya oleh Considine 1996 mendapati nilai rata-rata leptin pada kelompok obesitas adalah $31.301 \pm 24,1 \mathrm{pg} / \mathrm{ml}$. Soegondo dkk 2004 mendapatkan hasil rerata leptin pada pria dengan obesitas sentral $9.710 \mathrm{pg} / \mathrm{ml}$ sedangkan Awdah 2004 dan Ma dkk 2009 mendapatkan hasil yang hampir sama dengan rerata $23.150 \mathrm{pg} / \mathrm{ml}$ dan $24.580 \mathrm{pg} / \mathrm{ml}$ pada wanita obes normal. Khokhar dkk 2010 mendapati rerata kadar leptin pada wanita obes adalah

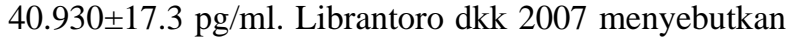
berdasarkan penelitian sebelumnya dibeberapa negara rerata kadar leptin normal berkisar 1.000-12.000 pg/ml. Hal ini menunjukkan bahwa kadar plasma leptin bervariasi dengan adanya variasi ras. Hasil penelitian ini menunjukkan tidak ada perbedaan yang nyata antara rerata kadar leptin pada kelompok obesitas viseral dengan non viseral. Hal ini disebabkan oleh karena leptin lebih terkait dengan akumulasi lemak ditubuh dan bukan pada region dimana lemak berada. Obesitas viseral tidak semata-semata menggambarkan kandungan lemak dalam tubuh tetapi lebih menunjukkan regio dari lemak berada. karena obesitas viseral merupakan akumulasi lemak pada lapisan viseral yang terdapat pada rongga abdomen. Leptin adalah hormone yang disekresi oleh sel lemak dengan proporsi terhadap penyimpanan lemak tubuh (Friedman, 1998) sehingga konsentrasi leptin dalam sirkulasi bersifat parallel terhadap IMT, persentase lemak tubuh dan berat lemak tubuh total (Considine, 1996). Almeida 2006 mendapati bahwa konsentrasi serum leptin berkorelasi kuat dengan ukuran obesitas seperti IMT atau persentase lemak tubuh. Selain itu produksi leptin pada jaringan adipose dibawah regulasi nutrisi, hormonal dan neural (Fruhbeck, 2001).

Hasil penelitian ini juga mendapati kadar leptin pada wanita lebih tinggi dari pria pada kedua kelompok baik obesitas viseral maupun non viseral. Pada obesitas viseral perbedaan yang didapat cukup kuat dan nyata $(\mathrm{p}<0.05)$. hasil ini sejalan dengan beberapa penelitian sebelumnya yang menyatakan bahwa terdapat perbedaan kadar leptin pada wanita dan pria. Shankar dkk 2010 mendapati bahwa kadar leptin pada wanita lebih tinggi dari pria. Khokhar dkk 2010 mendapati rerata kadar leptin pada wanita obes adalah

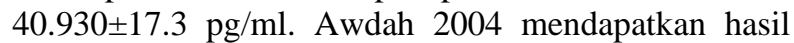
kadar leptin pada wanita obesitas sebesar 23.150 \pm 6.73 pg/ml sedangkan Librantoro 2009 mendapati kadar

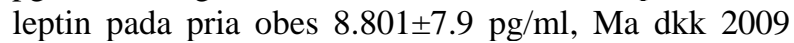
memperoleh hasil kadar leptin lebih tinggi pada wanita

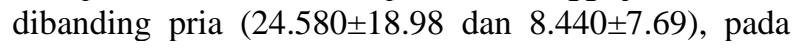
wanita juga ditemukan hampir dua kali lipat konsentrasi leptin yang tinggi (Kratzsch, 2002). Rentang nilai normal serum leptin pada wanita yaitu 3877 - 77,273 pg/mL sedangkan pria 2205 - 11,149 $\mathrm{pg} / \mathrm{mL}$. Hal ini kemungkinan berkaitan dengan pengaruh hormonal dimana teori menyebutkan bahwa estrogen dan prolaktin merupakan stimulator terhadap sintesis dan sekresi leptin sehingga semakin banyak estrogen maka kadar leptin akan semakin tinggi. Hormone estrogen dan prolaktin adalah hormone yang terdapat pada wanita sebaliknya hormon androgen 
merupakan inhibitor terhadap sintesis leptin dan lebih banyak didapat pada pria.

\section{Perbandingan Tekanan Darah dengan obesitas}

Tekanan darah systole pada obesitas viseral lebih tinggi dibanding non viseral $(\mathrm{p}<0.05)$ sedangkan tekanan darah diastole dijumpai lebih tinggi pada obesitas viseral dibanding non viseral namun tidak signifikan ( $>>0.05)$. hasil penelitian ini sejalan dengan penelitian sebelumnya yang menyatakan bahwa obesitas viseral cenderung lebih mudah mengalami hipertensi dibanding obesitas viseral. Penentuan hipertensi didasarkan pada peningkatan tekanan darah systole dan diastole. Ketika tekanan darah sistolik dan diastolic berada pada kategori yang berbeda maka dipilih kategori yang lebih tinggi untuk mengklasifikasikan tekanan darah individu (Mancia dkk, 2007). Studi prospektif dengan menggunakan pengukuran antropometri mendapati bahwa obesitas viseral memiliki kaitan erat dengan hipertensi, diabetes dan penyakit kardiovaskuler (Tchernof, 2007). Klein dan Romijn 2008 juga menyatakan bahwa obesitas abdominal atau viseral berhubungan lebih kuat dengan hipertensi dan dislipidemia. Hal ini kemungkinan disebabkan karena jaringan lemak viseral (VAT) memiliki reseptor glukokortikoid dan androgen lebih banyak, metabolism yang lebih aktif, lebih sensitive terhadap lipolisis dan lebih resisten insulin dibanding jaringan lemak subkutan (SCAT). VAT memiliki kapasitas lebih besar menghasilkan FFA, meningkatkan glukosa dan lebih sensitive terhadap stimulasi adrenergic. Aktivitas adrenergic diketahui berkontribusi terhadap peningkatan tekanan darah (Ibrahim, 2009). Penelitian sebelumnya menunjukkan bahwa pemberian $\alpha$-adrenergik dan $\beta$ - adrenergic blockers, mencegah kenaikan tekanan darah pada anjing yang diberi diet tinggi lemak. Mekanisme kerjanya dengan menstimulasi pusat reseptor $\alpha_{2}$ dan mengurangi aktivitas SNS. Kombinasi blockade $\alpha$ adrenergik dan $\beta$ - adrenergic yang diberikan pada pasien obes yang hipertensi selama 1 bulan menurunkan tekanan darah pada pasien. Temuan ini menunjukkan bahwa peningkatan aktivitas adrenergic berkontribusi terhadap perkembangan hipertensi baik pada hewan percobaan dan manusia (Hall dkk , 2010)

\section{Perbandingan Leptin dengan Tekanan Darah}

Berdasarkan hasil penelitian ini didapati tidak ada perbedaan antara obesitas viseral dan non viseral untuk perbandingan kadar leptin dengan tekanan darah. Hasil yang didapat memiliki kecenderungan yang sama dimana semakin tinggi kadar leptin maka tekanan darah baik sistolik dan diastolic akan rendah. Hubungan antara kadar leptin dan tekanan darah menunjukkan korelasi yang negative. Hal ini bisa dilihat dari gambar 3 dan 4. Selain itu perbandingan antara tekanan darah subjek dengan kadar leptin yang telah diperiksa tidak menunjukkan perbedaan yang berarti. Antara kategori tekanan darah normal, prehipertensi, hipertensi grade 1 dan hipertensi grade 2 jika dilihat rata-rata kadar leptinnya hampir sama. Kadar leptin tertinggi didapat dari subjek yang memiliki tekanan darah normal, sebaliknya kadar leptin yang rendah didapat dari subjek yang tekanan darahnya masuk kategori hipertensi grade 2. Hasil penelitian ini berbeda dari peneliti lain seperti Ma dkk tahun 2004 yang mendapati bahwa kadar leptin berhubungan dengan tekanan darah dan hipertensi. Khokhar dkk tahun 2010 juga mendapati korelasi positif antara tekanan darah dan leptin secara signifikan ditemukan pada wanita hipertensi baik obes maupun normal. Namun hasil ini sejalan dengan penelitian Almeida tahun 2006 yang mendapati bahwa kadar leptin memiliki hubungan yang signifikan dengan variable antropometri tetapi tidak dengan tekanan darah. Hal ini mungkin terjadi karena adanya perbedaan kriteria sampel juga adanya variasi ras karena kadar plasma leptin bervariasi dengan adanya variasi ras (Librantoro, 2007). Efek depressor yang dimiliki leptin juga bisa menyebabkan penurunan tekanan darah karena kondisi leptin yang tinggi bisa menimbulkan peningkatan NO yang pada akhirnya akan menyebabkan vasodilatasi pembuluh darah dan mengakibatkan penurunan tekanan darah (Rahmouni \& Haynes, 2004). Brook et al tahun 2007 mendapati bahwa kondisi hiperleptinemia meningkatkan fungsi endotel tetapi tidak menaikkan tekanan darah. Penjelasan lain bahwa efek simpatis leptin kemungkinan tidak cukup kuat untuk menghasilkan peningkatan tekanan darah yang signifikan meskipun efek pressor leptin melalui SNS menyebabkan retensi garam dan mengakibatkan hipertensi (Aneja et al, 2004). Lembo et al 2000 menyebutkan bahwa leptin juga memiliki efek hipotensi. Efek ini muncul karena pengaruh leptin pada tekanan darah merupakan hasil dari keseimbangan antara peningkatan aktivitas saraf simpatis dengan efek hipotensi leptin. Pada keadaan tertentu bila peningkatan aktifitas simpatis oleh leptin melebihi efek hipotensinya, maka terjadilah peningkatan tekanan darah. Hal lain yang berperan adalah factor sirkulasi. Martin et al 2008 menyebutkan bahwa factor-faktor sirkulasi ekstrasel yang berikatan dengan leptin dapat mempengaruhi aktifitas leptin. Reseptor leptin soluble ObRe diketahui berikatan dengan leptin disirkulasi dan dapat mengurangi konsentrasi dan aktifitas leptin yang bebas. Sebagaimana diketahui bahwa besar dan kecilnya efek leptin tergantung dari banyaknya leptin yang bebas. Hal ini mungkin bisa menjadi alasan mengapa tidak semua subyek obes mengalami hipertensi.

\section{KESIMPULAN}

Berdasarkan hasil penelitian tidak didapati perbedaan kadar leptin antara obesitas viseral dan non viseral ( $>0.05)$, karena leptin lebih terkait dengan akumulasi lemak di tubuh bukan pada daerah dimana lemak itu berada.Dari hasil pemeriksaan tekanan darah diperoleh perbedaan antara obesitas viseral dan non viseral dimana Tekanan darah sistolik secara signifikan $(\mathrm{p}<0.05)$ ditemukan lebih tinggi pada kelompok 
obesitas viseral dibanding kelompok obesitas non viseral. Hal ini dikarenakan visceral adipose tissue (VAT) lebih sensitive terhadap stimulasi adrenergic, yang mana aktivitas adrenergic berkontribusi terhadap peningkatan tekanan darah.Hasil penelitian ini juga menunjukkan bahwa kadar leptin lebih tinggi pada wanita dibanding pria karena wanita dominan dengan hormone estrogen yang menstimulasi produksi leptin sedangkan pria dominan dengan hormone androgen yang menghambat produksi leptin. Pada obesitas viseral dan non visceral didapati semakin tinggi kadar leptin maka tekanan darah semakin rendah, karena kondisi hiperleptinemia juga bisa menyebabkan peningkatan nitric oxide (NO) sehingga menimbulkan vasodilatasi pembuluh darah dan berefek terhadap penurunan tekanan darah atau efek simpatis leptin mungkin tidak mampu menaikkan tekanan darah.

\section{SARAN}

Untuk kelanjutan penelitian dan pengamatan yang lebih mendalam perlu disarankan sebegai berikut:

- Penggunaan metode pengukuran yang lebih baik seperti MRI disetiap pelayanan kesehatan sehingga penentuan kategori obesitas bisa lebih tepat.

- Penanganan terhadap kasus yang berhubungan dengan obesitas dan tekanan darah hendaknya lebih spesifik untuk kelompok umur seperti anak-anak yang obes, remaja dan lansia karena perbedaan usia dan hormonal juga berpengaruh terhadap kadar leptin dan tekanan darah seseorang.

\section{DAFTAR PUSTAKA}

Aizawa AM et al, Pathophisiologycal role of leptin in obesity-related hypertension, J Clin Invest 2000, 105:1243-1252

Almeida B et al, Leptin is not associated independently with hypertension in Japanese-brazilian women, Braz J Med Biol Res, 2006:39(1)99105.

Alvarez GE, et al,Sympathetic neural activation in visceral obesity. Circulation 2002:106 : 2533 2536

Aneja A, et al, Hypertension and Obesity, The Endocrine Society 2004:59:. 169 -205

Awdah M, Relationship between arterial blood pressure, angiotensin II and leptin, J Med Lab Sci.(ESIC)Egypt:2004:13(2)

Bravo PE et al, Leptin and hypertension in obesity, Vaskuler health and risk management 2006:2(2):163-169

Brook RD et al, Blood Pressure and Vascular Effects of Leptin in Humans, Metabolic Syndrom and Related Disorder, 2007 Volume 5, Number 3: 270-275.

Considine RV et al, Serum immunoreactive-leptin concentrations in normal-weight and obese human, N Engl J Med 1996;334:292-5
Correia M, Haynes GW, Does selective leptin resistance cause obesity-related hypertension?, Rev Brass Hipertens 2008:15(4):189-194

Direktorat Kesehatan dan Gizi Masyarakat:Laporan pembangunan kesehatan dalam RPJMN 20102014, Badan perencanaan pembangunan nasional 2009

Ekowati R,Sulistyowati T, Prevalensi Hipertensi dan Determinannya di Indonesia. Maj Kedokt Indon 2009:59(12):580-587

Francischetti EA, Genelhu VA, Obesity-hypertension: an ongoing pandemic, int $\mathrm{J}$ Clin Pract 2007:61:2:269-280

Friedman JM, Halaas JL: Leptin and the regulation of body weight in mammals. Nature, 1998: 395 : $763-770$

Fruchbeck G, Nutrition Society Medal Lecture A heliocentric view of leptin, Proceedings of the Nutrition Society, 2001: 60:301-318

Hall JE: The kidney, hypertension, and obesity. Hypertension 2003:41 : 625 -633

Henriksen $\mathrm{H}$ et al, Elevated circulation leptin levels in arterial hypertension: relationship to arteriovenous ovelflow and extraction of leptin, Clinical science, 2000:99:527-534.

Ibrahim MM, Subcutaneous and visceral adipose tissue: structural and functional differences, Journal compilation (c) International Association for the Study of Obesity. obesity reviews 11 2009:11-18.

Kearney PM, Whelton M, Reynolds K et al. Global burden of hypertension: analysis of worldwide data. Lancet 2005; 365: 217-23.

Khokhar KK, Sharda S, Kaur G, Correlation between leptin level and hypertension in normal and obese pre- and postmenopausal women. European Journal of Endocrinology, 2010:163:873-878.

Klein S \& Romijn JA, Obesity in Kronenberg HM et al, ed. Williams Textbook of Endocrinology $11^{\text {th }}$ ed, vol. 2, Philadelphia: Saunders an imprint of Elsevier Inc, 2008; p. 1563-1575.

Kratzsch J et al,Circulating Soluble Leptin Receptor and Free Leptin Index during Childhood, Puberty, and Adolescence, The Journal of Clinical Endocrinology \& MetabolismOctober 1, 2002 vol. 87 no. 10 4587-4594

Lembo G, et al. Leptin Induces Direct Vasodilation Through Distinct Endothelial Mechanism, Diabetes 2000:49:293-7

Librantoro et al, Correlation between plasma leptin and endothelin-1 plasma level in obese hypertensive subjects, J Kardion Ind 2007:28:246-255.

Ma D et al. Leptin is associated with blood pressure and hypertension in women from the National Heart, Lung, and Blood Institute Family Heart Study. Hypertension. 2009 ; 53 : 473 -479.

Mancia G et al,2007 Guidelines for the Management of Arterial Hypertension, The Task Force for the Management of Arterial Hypertension of the 
European Society of Hypertension (ESH) and of the European Society of Cardiology (ESC), Journal of Hypertension 2007, Vol 25:(6):11051187.

Martin SS, Qasim A, Reilly MP. MB,Leptin Resistance A Possible Interface of Inflammation, and Metabolism in Obesity-Related Cardiovascular Disease, J Am Coll Cardiol 2008;52:1201-10.

Rahmouni K, et al,Role of selective leptin resistance in diet-induced obesity hypertension, Diabetes 2005:54:2012-2018

Rahmouni K, Haynes WG, Leptin and cardiovascular system, The Endocrine Society 2004: 225-240.

Sastroasmoro S, Ismael S, Dasar-dasar metodologi penelitian klinis edisi ke-4, Sagung Seto, Jakarta, 2011.

Shankar A, Xiao Jie, Positive relationship between plasma leptin level and hypertension, Hypertension, 2010:56:623-628.

Shintani $\mathrm{M}$ et al, Leptin gene polymorphisme is associated with hypertension independent of obesity, J Clin Endocrinol Metab 2002:87:2909-2912.

Soegondo S, Hubungan leptin dengan dislipidemia pada obesitas sentral, kajian terhadap small dense LDL, Jakarta: universitas Indonesia, 2004
Tchernof A, Visceral adipocytes and the metabolic syndrome. Nutrition Reviews. 2007:24:29-6.

Wajchenberg B L, Subcutaneous and Visceral Adipose Tissue: Their Relation to the Metabolic Syndrome, Endocrine Reviews 21:697-738, 2000

WHO/SEARO. Noncommunicable diseases in the South-East Asia region. Situation and response . India: WHO 2011.

Wilson PWF,et al. Overweight and obesity as determinants of cardiovascular risk.The Framingham Experience. Arc.Intern.Med. 2002; 162: 1867-72. 